\title{
A New Case of Primary Signet Ring Cell Carcinoma of the Uterine Cervix: A Case Report and Review of the Literature
}

Doghri $\mathbf{R}^{1}$, Tounsi $\mathbf{N}^{2 *}$, Slimane $\mathbf{M}^{2}$, Boujelbene $\mathbf{N}^{1}$, Driss $\mathbf{M}^{1}$, Charfi $\mathbf{L}^{1}$, Rahal $\mathrm{K}^{\mathbf{2}}$ and $\mathbf{M r a d} \mathrm{K}^{1}$

${ }^{1}$ Department of Pathology, Salah-Azaiez Institute, Boulevard, Tunis, Tunisia

${ }^{2}$ Department of Surgery Carcinologique, Salah-Azaiez Institute, Boulevard, Tunis, Tunisia

\begin{abstract}
Primary signet-ring cell carcinoma of cervix is extremely rare in the literature. Usually Signet-Ring Cell Carcinomas (SRCCs) of the cervix are metastatic from a primary gastric, colonic, ovarian, or breast carcinoma. A 48-year-old woman was referred to our Department due to persistent abnormal vaginal bleeding during the last two months. Gynecologic examination revealed cervical tumor. Biopsy revealed a signet ring cell type of mucinous adenocarcinoma. Extensive systemic examination reveals liver metastases biopsies confirmed. The patient was treated with palliative chemotherapy. The prognosis of primary signet ring cell adenocarcinoma of the uterine cervix is still unclear because of the rare incidence of cases. In this report we reviewed the literature to identify the clinical, pathological and immunohistochemical features of this rare malignancy.
\end{abstract}

Keywords: Cervix neoplasms; Signet ring cell carcinoma; Immunohistochemical; Adenocarcinoma

\section{Introduction}

Carcinoma of the uterine cervix is the most common malignancy in female genital tract in developing countries [1]. The current frequency of cervical adenocarcinoma is $10 \%$ to $25 \%$ of all the cervical carcinomas in developed countries and most of them are endocervical type [1].

Mucinous adenocarcinoma of the cervix was subdivided into 5 subtypes: endocervical, intestinal, signet-ring cell, minimal deviation, and villoglandular [2]. Adenocarcinomas with signet ring cell are mostly metastatic from gastric, breast, colonic or ovarian carcinomas and primary tumor is extremely rare [1-3]. The prognosis of primary signet-ring cell carcinoma (PSRCCs) of the cervix is not well known as a result of the small number of case reports.

We describe a case of primary adenocarcinoma of the uterine cervix, signet-cell type. In addition, we reviewed all reported cases in the literature, to the best of our knowledge.

\section{Case Report}

A 48-year-old woman, gravida seven, para five, aborta 2, married at the age of 18 not yet menopause and her medical and family history was unremarkable. She was a heavy smoker (tow pack/day) for 10 years, no alcohol, and used oral contraceptives on and off for about 10 years. She was admitted to our hospital for spontaneous and intermittent abnormal vaginal bleeding which had been present during the last two months. Gynecological examination revealed diffuse enlargement of the cervix which had been replaced by an exophytic ulcerated, reddish lesion with distal parametrial infiltration. We performed a cervical biopsy and endocervical curettage. Microscopic examination shows cells with eccentric hyperchromatic nuclei and large mucin filled cytoplasmic vacuoles growing in clusters and in nests or columns within pools of extracellular mucin (signet-ring cells) (Figures 1-3). An extensive immunohistochemical evaluation of the biopsies was performed. The neoplastic cells were diffusely positive for p16, Cytokeratin 7 and carcinoembryonic antigen, whereas cytokeratin 20, chromogranin A, synaptophysin, vimentin and hormonal (estrogens and progesterone) receptors were negative. Abdominal pelvic magnetic resonance imaging (MRI) demonstrated about $53 \mathrm{~mm} \times 36 \mathrm{~mm}$ size mass in the endocervical canal. Chest X-ray, gastroscopy, colonoscopy

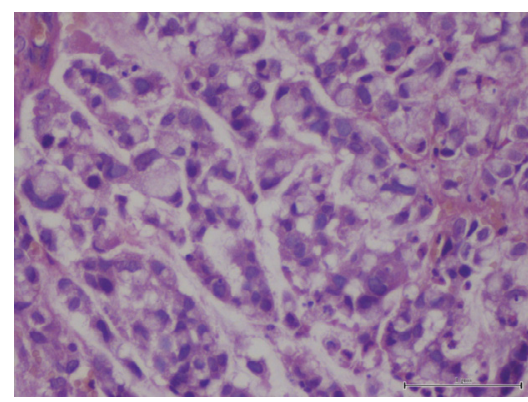

Figure 1: Microscopic examination shows cells with eccentric hyperchromatic nuclei and large mucin filled cytoplasmic vacuoles growing in clusters and in nests or columns within pools of extracellular mucin (signet-ring cells) $(\times 400)$.

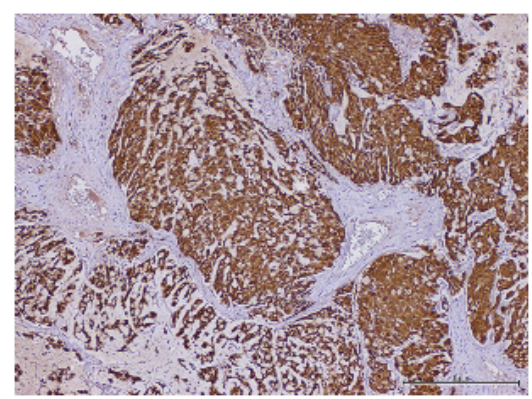

Figure 2: Immunohistochemical analysis showed positivity to p16 (× 200).

*Corresponding author: Tounsi N, Department of Surgery Carcinologique, Salah-Azaiez Institute, Boulevard of 9-Avril, 1001 Tunis, Tunisia, Tel:71563980 E-mail: Neserine.tounsi@gmail.com

Received August 24, 2017; Accepted October 11, 2017; Published October 16 2017

Citation: Doghri R, Tounsi N, Slimane M, Boujelbene N, Driss M, et al. (2017) ANew Case of Primary Signet Ring Cell Carcinoma of the Uterine Cervix: A Case Report and Review of the Literature. J Cancer Sci Ther 9: 713-716. doi:10.4172/19485956.1000496

Copyright: ( 2017 Doghri R, et al. This is an open-access article distributed under the terms of the Creative Commons Attribution License, which permits unrestricted use, distribution, and reproduction in any medium, provided the original author and source are credited. 


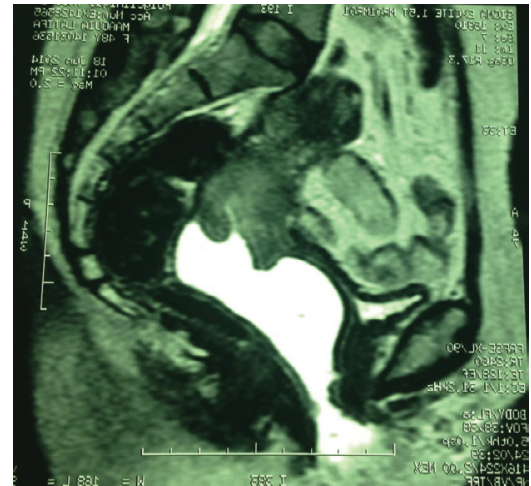

Figure 3: Abdominopelvic magnetic resonance imaging (MRI): the tumor measured $53 \mathrm{~mm} \times 36 \mathrm{~mm}$ size in the endocervical canal. Induration extended to the parametria. total, oral endoscopy and mammography, failed to show any other primary tumor. We practiced an abdominal pelvic scanner which revealed lombo-aortic adenopathy as well as hepatic metastasis biopsyconfirmed. All these results were consistent with a primary PSRCC FIGO (2009) cervical tumor stage IVB. The patient was referred to medical oncology for palliative treatment. Cisplatin has been indicated at doses $50 \mathrm{mg} / \mathrm{m}^{2}$ once every 3 weeks. But, his health condition had severely and rapidly deteriorated, therefore she doesn't receive chemotherapy. She was deceased three months later.

\section{Discussion}

The most common adenocarcinoma of the uterine cervix is the usual endocervical type [1]. Mucinous adenocarcinoma of signet-ring cell type is very rare [4,5]. Usually, signet-ring cell differentiation found in cervical carcinoma strongly suggests a metastatic carcinoma usually from a gastro-intestinal, appendicular, mammary or ovarian origin

\begin{tabular}{|c|c|c|c|c|c|c|c|c|}
\hline Authors, years & Age (yrs) & Presenting symptoms & $\begin{array}{l}\text { FIGO } \\
\text { stage }\end{array}$ & $\begin{array}{l}\text { Immunohistochemical studies } \\
\text { other than ER and PR }\end{array}$ & ER, PR & HPV & Treatment & Outcome \\
\hline Moll et al. [9] & 50 & $\begin{array}{c}\text { Post-coital vaginal bleeding, } \\
\text { menometrorrhagia }\end{array}$ & III & NA & NA & NA & Sx , RT & DOD $10 \mathrm{mo}$ \\
\hline \multicolumn{2}{|c|}{ Mayorga et al. [6] } & \multirow{2}{*}{ Post-coital bleeding } & \multirow{2}{*}{$\mathrm{lb}$} & \multirow{2}{*}{ NA } & \multirow{2}{*}{ NA } & \multirow{2}{*}{ NA } & \multirow{2}{*}{ Pre-chemo, Sx } & \multirow{2}{*}{ NED $35 \mathrm{Mo}$} \\
\hline case (1) & 68 & & & & & & & \\
\hline case (2) & 74 & Post-menopausal bleeding & $\mathrm{lb}$ & NA & NA & NA & Sx & NED $25 \mathrm{Mo}$ \\
\hline \multicolumn{2}{|c|}{ Haswani et al. [5] } & \multirow{3}{*}{$\begin{array}{l}\text { Post-coital vaginal bleeding } \\
\text { In both cases }\end{array}$} & \multirow{2}{*}{ III } & \multirow{2}{*}{ NA } & \multirow{2}{*}{ ER: - } & \multirow{2}{*}{$\begin{array}{l}\text { HPV type } \\
18:+\end{array}$} & \multirow{2}{*}{$\begin{array}{c}\text { Palliative RT and } \\
\text { chemo }\end{array}$} & \multirow{2}{*}{ DOD $10 \mathrm{mo}$} \\
\hline case (1) & 33 & & & & & & & \\
\hline case (2) & 38 & & $\mathrm{lb}$ & NA & ER: -, R: - & NA & Sx and RT & NED $18 \mathrm{Mo}$ \\
\hline Cardosi et al. [10] & 53 & Perimenopausal bleeding & $\mathrm{lb}$ & NA & $\mathrm{ER}+\mathrm{PR}+$ & NA & Sx RT Chemo & NED 6 Mo \\
\hline Moritani et al. [14] & 29 & $\begin{array}{c}\text { Persistent abnormal genital } \\
\text { Bleeding }\end{array}$ & III & $\begin{array}{l}\text { Positive for CK, MUC5AC Negative } \\
\text { for vimentin, MUC2, MUC6 }\end{array}$ & ER: -, PR: - & - & Chemo & NED 6 Mo \\
\hline Insabato et al. [8] & 46 & $\begin{array}{c}\text { Vaginal bleeding in cervical } \\
\text { polypoid lesion }\end{array}$ & $\mathrm{lb}$ & NA & NA & NA & Sx,RT,Chemo & NED 8 Yrs \\
\hline & & & & $\begin{array}{c}\text { Positive for CK AE1-AE3, CK } \\
\text { 20, CEA, chromogranin A, } \\
\text { synaptophysin }\end{array}$ & & & & \\
\hline Suárez et al. [7] & 80 & Vaginal discharge & IIIb & $\begin{array}{l}\text { Negative for vimentin, } \\
\text { S-100 protein, HMB-45, } \\
\text { adrenocorticotropic hormone, } \\
\text { prolactin, thyroid-stimulating } \\
\text { hormone, follicle-stimulating } \\
\text { hormone, luteinizing hormone, } \\
\text { growth hormone, GCDFP } 15\end{array}$ & NA & NA & Rx Chemo & DOD $18 \mathrm{Mo}$ \\
\hline $\begin{array}{l}\text { Mc Cluggage et } \\
\text { al. [17] }\end{array}$ & \multirow[t]{2}{*}{ NA } & \multirow[t]{2}{*}{ Two cases NA } & \multirow[t]{2}{*}{ NA } & Positive for CK 7 and CK 16 & \multirow[t]{2}{*}{ NA } & \multirow[t]{2}{*}{ NA } & \multirow[t]{2}{*}{ NA } & \multirow[t]{2}{*}{ NA } \\
\hline ( 2 cases $)$ & & & & Negative for CK 20 and CDX2 & & & & \\
\hline \multicolumn{2}{|c|}{ Versas et al. [13] } & Thromboembolic events & IV & Positive for $\mathrm{p} 16$ and CK 7 Negative & \multirow{3}{*}{ ER: -, PR: - } & \multirow{3}{*}{+} & \multirow{2}{*}{ Chemo } & \multirow{2}{*}{ DOD 7 wks } \\
\hline (2009) [3] & 36 & (Trousseau Syndrome) & IV & for CK 20, CDX2 and Dpc4. & & & & \\
\hline Case (2) & 43 & $\begin{array}{l}\text { Metastases of lung and } \\
\text { lymph nodes }\end{array}$ & IV & $\begin{array}{c}\text { positive for } \mathrm{p} 16 \text { and } \mathrm{CK} \\
\text { negative for CK } 20, \mathrm{CDX} 2 \text { and } \\
\text { mammoglobin }\end{array}$ & & & Chemo & DOD 2 \\
\hline Lowery et al. [15] & 60 & Post-menopausal bleeding & $\mathrm{lb} 1$ & NA & NA & NA & $\begin{array}{l}\text { RT brachytherapy } \\
\text { Sx }\end{array}$ & $\begin{array}{l}\text { DOD }>10 \\
\text { years }\end{array}$ \\
\hline Balci et al. [2] & 53 & Post-menopausal bleeding & $\mathrm{Ilb}$ & $\begin{array}{c}\text { Positive for CK, p16, CEA, MUC1, } \\
\text { and MUC5. Negative for CK 20, } \\
\text { GCDFP15, MUC2, chromogranine, } \\
\text { synaptophysin, PGP 9.5, CD56, } \\
\text { vimentin, CDX-2, TTF-1, and } \\
\text { mammaglobin }\end{array}$ & ER: -, PR. - & $\begin{array}{c}\text { HPV type } \\
18:+\end{array}$ & Sx & NR \\
\hline
\end{tabular}


Citation: Doghri R, Tounsi N, Slimane M, Boujelbene N, Driss M, et al. (2017) A New Case of Primary Signet Ring Cell Carcinoma of the Uterine Cervix: A Case Report and Review of the Literature. J Cancer Sci Ther 9: 713-716. doi:10.4172/1948-5956.1000496

\begin{tabular}{|c|c|c|c|c|c|c|c|c|}
\hline $\begin{array}{c}\text { Yoon et al (2011) } \\
{[1]}\end{array}$ & 47 & post-coital bleeding & $\mathrm{lb}$ & Positive for $\mathrm{p} 53$ and $\mathrm{Rb}$ & NA & NA & Sx & NED 6 mo \\
\hline $\begin{array}{l}\text { Giordano et } \\
\text { al. [4] }\end{array}$ & 45 & Vaginal discharge & $\mathrm{Ilb}$ & $\begin{array}{l}\text { Positive for CK } 7, \text { CA-125, CEA } \\
\text { and p16 Negative for vimentin, }\end{array}$ & NA & $\begin{array}{l}\text { HPV type } \\
18:+\end{array}$ & Sx & NA \\
\hline \multirow{2}{*}{$\begin{array}{l}\text { O. Kaidar-Person } \\
{[16]}\end{array}$} & \multirow[t]{2}{*}{37} & \multirow[t]{2}{*}{ post-coital bleeding } & \multirow[t]{2}{*}{ Ilb2 } & \multirow{2}{*}{$\begin{array}{l}\text { Negative for chromogranin } \\
\text { synaptosin, CEA. }\end{array}$} & \multirow[t]{2}{*}{ NA } & \multirow[t]{2}{*}{ NA } & $\begin{array}{l}\text { concomitant chemo } \\
\text { radiotherapy }\end{array}$ & \multirow[t]{2}{*}{ NED 4 mo } \\
\hline & & & & & & & brachytherapy Sx & \\
\hline \multirow[b]{2}{*}{$\begin{array}{l}\text { Washimi et al. } \\
{[11]}\end{array}$} & \multirow[b]{2}{*}{31} & \multirow[b]{2}{*}{ Abnormal vaginal bleeding. } & \multirow[b]{2}{*}{ Ila } & $\begin{array}{l}\text { Positive for MUC2, CDX2, CEA, } \\
\text { CK7. }\end{array}$ & \multirow[b]{2}{*}{ ER: -, PR: - } & \multirow[b]{2}{*}{$\begin{array}{l}\text { HPV type } \\
18:+\end{array}$} & \multirow[b]{2}{*}{ Sx and chemo } & \multirow[b]{2}{*}{$\begin{array}{l}\text { Disease-free } \\
\text { at } 41 \mathrm{mo}\end{array}$} \\
\hline & & & & $\begin{array}{l}\text { Negative for MUC1, MUC5AC, } \\
\text { MUC6, p53, CK20, TTF-1, } \\
\text { GCDFP-1, mammoglobin, } \\
\text { chromogranin-1, p16, HIK1083. }\end{array}$ & & & & \\
\hline \multirow{5}{*}{$\begin{array}{l}\text { Cracchiolo et al. } \\
\qquad[12]\end{array}$} & \multirow{5}{*}{64} & \multirow{5}{*}{ Abdominal fullness. } & \multirow{5}{*}{ IVB } & Cytokeratin 7, (CEA) & \multirow{5}{*}{$\mathrm{ER}:+, \mathrm{PR}:+$} & \multirow{5}{*}{-} & \multirow{5}{*}{ Palliative } & \multirow{5}{*}{ $\pm 3 \mathrm{mo}$} \\
\hline & & & & P16 positive & & & & \\
\hline & & & & (GCDFP), S-100 protein & & & & \\
\hline & & & & synaptophysin, (SMA) & & & & \\
\hline & & & & $\begin{array}{l}\text { CDX-2, colon carcinoma and } \\
\text { Cytokeratin } 20 \text { negative. }\end{array}$ & & & & \\
\hline \multirow{4}{*}{ Sal et al. [13] } & \multirow{4}{*}{48} & \multirow{4}{*}{ Postcoital vaginal bleeding } & \multirow{4}{*}{$\mathrm{lb}$} & Positivity for $\mathrm{p} 16, \mathrm{CDX}-2$ & \multirow{4}{*}{ ER: -, PR: - } & \multirow{4}{*}{$\begin{array}{l}\text { HPV type } \\
18:+\end{array}$} & \multirow{4}{*}{ Sx } & \multirow{4}{*}{$\begin{array}{l}\text { Disease-free } \\
\text { at } 18 \mathrm{mo}\end{array}$} \\
\hline & & & & MUC1, MUC2 and MUC5AC. & & & & \\
\hline & & & & Negativity for synaptophysin, & & & & \\
\hline & & & & chromogranin $\mathrm{A}$ and $\mathrm{CK}-20$ & & & & \\
\hline
\end{tabular}

CKCK: Cytokeratin; MUC: Mucin; TTF: Thyroid Transcripton Factor; GCDFP: Gross Cystic Disease Fluid Protein; ER: Estrogen Receptor; PR: Progesteron Receptor; NA: Not Available; Sx: Surgery; Rx: Radiation Therapy; DOD: Died of Disease; NED: Not Evidence of Disease; Mo: Months; Yrs: Years; Wks: Weeks; Chemo: Chemotherapy; CEA: Carcinoembryonic Antigen; CDX-2: Caudal-Type Homeobox 2; SMA: Smooth Muscle Actin; PGP: Protein Gene Product; TTF: Thyroid Transcripton Factor 1; PreChemo: Preoperative Chemotherapy

Table 1: Previous reported cases of primary cervical carcinoma containing signet-ring cell morphology.

$[1,6]$. To the best of our knowledge, only 20 cases (included our case) of primary cervical carcinoma containing signet-ring cell morphology have been reported in the literature (Table 1). In most cases of previous reports, the signet-ring cell component is included in a part of histological types [6]. All cases were admitted as primary only after a careful combined clinical, endoscopic and radiological investigation to rule out the presence of an occult primary site. Immunohistochemical and molecular studies have often provided important information for differential diagnosis. Several immunohistochemical markers have been used in the literature to support the primary origin of cervical cancer, although their usefulness is debatable. Indeed, primary cervical carcinoma can express colorectal antigens such as ACE, caudal-related homeoboxn (CDX-2) and cytokeratin 20 (CK20) [7,8]. Moreover, simultaneous positivity to ACE and keratin 7 do not differentiate between PCSRCC and gastric or mammary metastatic malignancy [5]. However, positivity for mammoglobin favors a mammary origin. No positive case of PCSRCC was reported [5]. Oestrogen and progesterone receptors have been tested in only 4 previous cases $[2,3,9]$ and these were present only in one example [10]. Neuroendocrine differentiations have been demonstrated in two cases $[7,10]$ but these markers were negative in our case. Positivity of Human Papillomavirus (HPV) DNA using molecular analysis provides diagnostic evidence of primary signet- ring cell carcinoma of the cervix $[4,5]$. The presence of HPV 18 has been determined in five cases of primary signet-ring cell carcinoma of the cervix $[4,7,11-13]$. No case was reported with negative p16 immunohistochemical staining [13]. In our case, as well as in some previous published examples of the PCSRCC, the primary cervical origin was supported by the presence of P16 Immunoreactivity [12,13], which may be considered a surrogate marker for HPV infection [4]. The absence of extra genital pathology, demonstrated by investigations at the moment of the diagnosis and later in the course of the disease, also supports this opinion [7]. The prognosis of primary signet-ring cell carcinoma of the cervix is not well known [1]. Ten patients had localized disease to the cervix and eight patients had advanced tumors
[2,4,5,7,10-14], in one cases with stage IV, was expired shortly after 3 months [12]. However, extended survival in a low-stage tumor was reported in two cases $[8,15]$. We have not a clear consensus; the treatment of this rare tumor joins the treatment recommendations for uterine cervix adenocarcinoma [16]. A resistance to radiotherapy and/ or chemotherapy was reported [3-5,7,9]. But it has been suggested that advanced stage disease is particularly aggressive $[4,7,12,14]$.

\section{Conclusion}

Primary signet-ring cell carcinomas of the cervix are rare and associated with a poor outcome [17]. Prognosis seems to be related to the clinical stage $[4,10]$. Awareness of this entity is important as it simulate metastatic signet-ring cell carcinoma. Clinical investigations and immunohistological studies are essentials for differential diagnosis $[4,8]$.

\section{Competing Interests}

The authors declare that they have no competing interests.

\section{Ethical Approval}

Our study did not require ethical form.

\section{Consent}

Written informed consent form was obtained from the patient for publication of this case report and images.

\section{References}

1. Yoon A, Kim SH, Kim HJ, Bae DS, Lee JW (2011) Primary signet ring cell carcinoma of the uterine cervix: A case report. KJOG 54: 570-573

2. Balci S, Saglam A, Usubutun A (2010) Primary signet-ring cell carcinoma of the cervix: Case report and review of the literature. Int J Gynecol Pathol 29 . 181-184

3. Veras E, Srodon M, Neijstrom ES, Ronnett BM. (2009) Metastatic HPV-related cervical adenocarcinomas presenting with thromboembolic events (Trousseau Syndrome): clinicopathologic characteristics of 2 cases. Int J Gynecol Pathol 28: 134-139. 
Citation: Doghri R, Tounsi N, Slimane M, Boujelbene N, Driss M, et al. (2017) A New Case of Primary Signet Ring Cell Carcinoma of the Uterine Cervix: A Case Report and Review of the Literature. J Cancer Sci Ther 9: 713-716. doi:10.4172/1948-5956.1000496

4. Giordano G, Pizzi S, Berretta R, D’Adda T (2012) A new case of primary signetring cell carcinoma of the cervix with prominent endometrial and myometria involvement: Immunohistochemical and molecular study and review of the literature. World. World J Surg Oncol 11: 10.

5. Haswani P, Arseneau J, Ferenzcy A (1998) Primary signet ring cell carcinoma of the uterine cervix: A clinicopathologic study of two cases with review of the literature. Int J Gynecol Cancer 8: 374-379.

6. Mayorga M, Garcia-Valtuille A, Fernandez F, Val-Bernal JF, Cabrera E (1997) Adenocarcinoma of the uterine cervix with massive signet-ring cell differentiation. Int J Surg Pathol 5: 95-100.

7. Suárez-Peñaranda JM, Abdulkader I, Barón-Duarte FJ, González Patiño E, Novo-Domínguez A, et al. (2007) Signet-ring cell carcinoma presenting in the uterine cervix: Report of primary and 2 metastatic cases. Int J Gynecol Pathol 26: $254-258$

8. Insabato L, Simonetti S, De Cecio R, Di Tuoro S, Bifulco G, et al. (2009) Primary signet-ring cell carcinoma of the uterine cervix with long term follow-up: case report. Eur J Gynaecol Oncol 28: 411-414.

9. Moll UM, Chumas JC, Mann WJ, Patsner B (1990) Primary signet ring cell carcinoma of the uterine cervix. N Y State J Med 90: 559-560.

10. Cardosi RJ, Reedy MB, Van Nagell JR, Spires SE (1990) Neuroendocrine signet ring cell adenocarcinoma of the endocervix. Int J Gynecol Cancer 9: 433-437.
11. Washimi K, Okose T, Noguchi A, Ono K, Kawachi K, et al. (2015) Diagnosis of primary pure signet-ring cell carcinoma of the cervix. Pathol Int 65: 393-395.

12. Cracchiolo B, Kuhn T, Heller D (2015) Primary signet ring cell adenocarcinoma of the uterine cervix- A rare neoplasm that raises the question of metastasis to the cervix. Gynecol Oncol Rep 16: 9-10.

13. Sal V, Kahramanoglu I, Turan H, Tokgozoglua N, Bese T, et al. (2016) Primary signet ring cell carcinoma of the cervix: $A$ case report and review of the literature. Int J Surg Case Rep 21: 1-5.

14. Moritani S, Ichihara S, Kushima R, Sugiura F, Mushika M, et al. (2004) Combined signet ring cell and glassy cell carcinoma of the uterine cervix arising in a young Japanese woman: A case report with immunohistochemical and histochemical analyses. Pathol Int 54: 787-792.

15. Lowery WJ, Difurio MJ, Sundborg MJ, Leath CA (2011) Cervical signet-ring cell carcinoma presenting as a synchronous primary carcinom a with uterine adenocarcinoma. Mil Med 174: 212-213.

16. Kaidar-Person O, Amit A, Berniger A, Ben-Yosef R, Kuten A, et al. (2013) Primary signet-ring cell adenocarcinoma of the uterine cervix: Case report and review of the literature. Eur J Gynaecol Oncol 34:353.

17. Mc Cluggage WG, Shah R, Connolly LE, Mc Bride HA (2008) Intestinal-type cervical adenocarcinoma in situ and adenocarcinoma exhibit a partial enteric immunophenotype with consistent expression of CDX2. Int J Gynecol Pathol 27: 92-100. 